JBL 136, no. 1 (2017): 208-212

doi: http://dx.doi.org/10.15699/jbl.1361.2017.1364

\title{
The Scholarly Network
}

\author{
NYASHA JUNIOR \\ nyasha.junior@temple.edu \\ Temple University, Philadelphia, PA 10122
}

Service is the rent we pay for a room on earth.

-Unknown author

I instruct my students to answer the exam question directly. That is, they must answer the question as I wrote it and not as they wish to reformulate it. I also tell my students to do as I say and not as I do. The editor has asked me and others to offer "personal reflections on whether and how your own work has been affected by recent events (high-profile murders of black people, including Trayvon Martin, Michael Brown, and Freddie Gray, as well as other black men, women, and children assaulted and murdered by law enforcement officials and others in the United States), including, if possible, one or two concrete examples of past, current, or future work."

The editor asks "whether" my work has been affected by these events. This question presumes that my work and I are separate, but as I am a black woman academic, my work and life are intertwined. It is not possible for me to remain unaffected by the murders of black people. Although I do not personally know the individuals who have been murdered, they are my kin. Although I do not know their families, I grieve with them. My work includes more than the items detailed in my annual faculty productivity report. I do not judge my success or productivity solely by standard academic metrics. My work involves not only what I publish but how I operate in the world and in this academic discipline. In this personal essay, I reflect on my motivation and efforts to support black and other underrepresented scholars through networking and social media.

Data from the Society of Biblical Literature (SBL) indicate that there are relatively few black biblical scholars in the United States. According to the 2015 SBL Society Report, "Presently, $85 \%$ of members who claim to be United States citizens are of European descent, 3.8\% are multiethnic, and 3.4\% are of African descent. Members of Asian descent account for 2.3\%, Latina/o descent totals 1.7\%, and 
Native American, Alaska Native, or First Nation descent is $0.2 \%$." Furthermore, the Society Report acknowledges, "Members of African descent have the highest representation of contingent faculty at $9.5 \%$ and the lowest representation of fulltime tenured faculty at $47.4 \%$." 2 As a group, black SBL members remain underrepresented and are least secure regarding tenure status.

Academia is not a warm, welcoming space, and it is much less so for underrepresented scholars. ${ }^{3}$ In many conversations with nonblack academics, I find that I may be one of the few black scholars they know. According to the 2013 American Values Survey by the Public Religion Research Institute (PRRI), the social networks of whites are 91 percent white. ${ }^{4}$ Just as our neighborhoods and faith communities are segregated, so are our scholarly networks. Academics rely on a host of informal communication networks for a variety of reasons. We may contact our graduate school cohort at "feeder" schools to ask if they have promising students who are applying for doctoral programs. We may e-mail our colleagues seeking names to include on lists of potential job candidates or keynote speakers. "I have never heard of her" is one of the worst things that can be said about a scholar. People need to know that you exist in order to invite you to collaborate on projects, contribute to edited volumes, or apply for fellowships. Black scholars who are not part of those networks may miss out on vital opportunities.

I am fortunate to have a tenure-track position, encouraging departmental colleagues, a wonderful therapist, and a loving family. I want to help other scholars who may not have the same support. I do not consider myself an activist; for me, that term suggests someone who is strongly committed to a particular organization, cause, or action on a regular basis. I do not consider myself a protester, although my family and I attend local meetings, protests, and vigils, including those in support of the \#SayHerName campaign. ${ }^{5}$ Instead, I feel an obligation to support others because my parents instilled in me the importance of "lifting as we climb." 6 That is,

${ }^{1}$ Society of Biblical Literature, 2015 Society Report, https://www.sbl-site.org/assets/pdfs/ SR2015_online.pdf, 22.

${ }^{2}$ Ibid., 23.

${ }^{3}$ See Gabriella Gutiérrez y Muhs et al., eds., Presumed Incompetent: The Intersections of Race and Class for Women in Academia (Boulder: University Press of Colorado, 2012); and Patricia Matthew, ed., Written/Unwritten: Diversity and the Hidden Truths of Tenure (Chapel Hill: University of North Carolina Press), 2016.

${ }^{4}$ Daniel Cox, Juhem Navarro-Rivera, and Robert P. Jones, Race, Religion, and Political Affiliation of American's Core Social Networks, PRRI, August 3, 2016, http://www.prri.org/ research/race-religion-political-affiliation-americans-social-networks/.

${ }^{5}$ \#SayHerName seeks to bring attention to the violence and police brutality experienced by black girls and women (African American Policy Forum, http://www.aapf.org/sayhername/).

6"Lifting as We Climb" was the motto of the National Association of Colored Women, which began in 1896. This association later became the National Association of Colored Women's Clubs; http://www.nacwc.org/aboutus/index.html. 
even as I attain some measure of individual success, I have a duty to assist other black people. My service to others does not have a particular label. I don't wear it on a t-shirt. It is simply an important and expected part of my work and life. Recent events have not affected my current research projects, but they have made me more resolute in operating within my sphere of influence as a black woman biblical scholar.

\section{Networking}

I reject a king-of-the-hill model of academia by sharing opportunities with other scholars. When I receive an invitation from a colleague, I may not be able to accept. Yet I fear that I may be one of few black scholars to receive an invitation, since I may be one of the only black scholars in the invitee's scholarly network. If I cannot accept an offer to speak or to contribute to an edited volume, I have a standing policy to decline politely and give three names. As I discuss on my blog, I suggest the names of three other scholars, especially those who are from traditionally underrepresented groups. ${ }^{7}$ By offering additional names, I expand opportunities for other scholars and create new connections in the field. I know that this strategy works because editors let me know that they appreciate the suggestions, and scholars let me know that they have accepted an invitation. I hope to model good citizenship by refusing to engage in competitiveness, greed, and backstabbing.

I try to facilitate networking among graduate students and scholars who are at earlier stages of their careers. Social gatherings can be difficult for many introverted academics, but especially for those from underrepresented groups. Still, getting to know scholars personally is an important part of being in the academy. When I am at meetings or conferences, I make a beeline for the person who looks most uncomfortable in the room or at the reception and introduce myself. I give her my business card and encourage her to contact me. If she seems receptive, I will invite her to join my table or offer to introduce her to a senior scholar who is present. As I develop relationships with these people, I let them know that I am available to listen confidentially and without judgment. I know the weariness and loneliness of being the only one like you in your department or institution. I am not a therapist or counselor, but, in my experience, it can be helpful just to have someone confirm that it's not all in your mind and to acknowledge and name the racism, sexism, and politics of the academy.

\section{Social media}

In addition to face-to-face networking in seeking to make academia a better place and space for black academics, I have become more active and outspoken on

${ }^{7}$ Nyasha Junior, "Speak Three Names," No Extra Credit, http://www.nyashajunior.com/ noextracredit/130820-speak-three-names. 
social media, especially in support of black academics. As my social media platform has grown, I have been deliberate about using social media to share my opinion, to disseminate resources, to facilitate networking, and to amplify the work of black and other underrepresented scholars. ${ }^{8}$ I have become more vocal in asking predominantly white institutions and white colleagues about their inattention to recent protests. For instance, after the murder of Michael Brown in Ferguson, Missouri, I tweeted several professional organizations asking how they planned to respond. The Wabash Center for Teaching and Learning e-mailed me immediately. [Disclosure: I am a Wabash Center grant awardee.] With none of the red tape or excuses I have come to expect from institutions, the Wabash Center began the Race Matters in the Classroom blog to convene conversations on issues of race in teaching theology and religion. ${ }^{9}$ For over a year, a diverse group of scholars contributed blog posts, and Wabash continues to host the blog on its website. It is possible that Wabash might have done something similar on its own, but I was glad to be able to facilitate this development by pointing out the need for some action.

Since the mainstream media anoints only a few scholars as thought leaders or public intellectuals, the work of some marginalized scholars remains underappreciated. In order to combat this, I signal boost the work of black academics on social media. Signal boosting involves posting with the aim of garnering greater attention for a person, a publication, or an event. Influenced by \#blktwitterstorians, a hashtag cofounded by Joshua Crutchfield and Aleia Brown for black historians, I created hashtag \#blkaarsbl. I use this hashtag to make more visible the work of black academics in religion and biblical studies. When I tweet a link to a book, I include the Twitter handle of the publisher and the scholar or the scholar's institution along with the hashtag. The scholars are usually grateful for the shout out, and both academics and nonacademics thank me for sharing these publications. I hope that others will "read, review, engage, cite, and assign" the work of these scholars. ${ }^{10}$

Even when not using \#blkaarsbl, I help to publicize events, calls for papers, and other articles and books related to religion and biblical studies that may be of interest to my social media community. I "tag" influential people on social media to bring things to their attention. I have created a "Black women of SBL" Twitter list that includes black women biblical scholars who are on Twitter. When I participate in Twitter chats, I focus on tweeting links to books and articles in religion and biblical studies. I use Pinterest to curate collections of these links. In addition,

${ }^{8}$ My Twitter account (@NyashaJunior) was included on a list of fifteen indispensable academic Twitter accounts (Andy Thomason, "Here Are 15 Indispensable Academic Twitter Accounts," Chronicle of Higher Education, March 22, 2016, http://www.chronicle.com/blogs/ ticker/here-are-15-indispensable-academic-twitter-accounts/109598).

${ }^{9}$ See Race Matters in the Classroom blog, http://wabashcenter.typepad.com/antiracism_ pedagogy/.

${ }^{10}$ Nyasha Junior, An Introduction to Womanist Biblical Interpretation (Louisville: Westminster John Knox, 2015), 131. 
I live-tweet almost any conference or lecture that I attend. For me, it is a way to share the conversations that are taking place among scholars especially for those who would not or could not attend the conference. In addition, I post images of gatherings of black scholars on social media, including Instagram and Facebook. It is fun to see friends, but it also makes black scholars more visible. These images show students, scholars, and others that black scholars exist and are active in the guild. It says that we are here and that we belong within the wider scholarly network. 